\title{
VASOACTIVITY OF THE GASOTRANSMITTERS HYDROGEN SULFIDE AND CARBON MONOXIDE IN THE CHICKEN DUCTUS ARTERIOSUS
}

\author{
S. van der Sterren, P. Kleikers, L.J. Zimmermann, E. Villamor
}

Pediatrics, Maastricht University Medical Center (MUMC+), GROW School, Maastricht, The Netherlands

Background: Besides nitric oxide (NO) and carbon monoxide (CO), hydrogen sulfide $\left(\mathrm{H}_{2} \mathrm{~S}\right)$ is a third gaseous messenger which may play a role in controlling vascular tone and has been proposed to serve as an $\mathrm{O}_{2}$ sensor. We aimed to investigate whether exogenous $\mathrm{H}_{2} \mathrm{~S}$ and $\mathrm{CO}$ are vasoactive in the chicken DA and play a role in ductal $\mathrm{O}_{2}$ sensing.

Methods: We investigated, using wire myography, the mechanical responses induced by the $\mathrm{H}_{2} \mathrm{~S}$ donor $\mathrm{Na}_{2} \mathrm{~S}$ $(1 \mu \mathrm{M}-1 \mathrm{mM})$ and by authentic $\mathrm{CO}(0.1 \mu \mathrm{M}-0.1 \mathrm{mM})$ in DA rings from 19-d chicken embryos. We also evaluated the effects on ductal reactivity of the precursors and inhibitors of the endogenous synthesis of $\mathrm{H}_{2} \mathrm{~S}$ and $\mathrm{CO}$.

Results: $\mathrm{Na}_{2} \mathrm{~S}$ elicited a $100 \%$ relaxation $\left(\mathrm{pD}_{2} 4.02\right)$ of $\mathrm{O}_{2}$-contracted and a $50.3 \%$ relaxation of $\mathrm{KCl}$ contracted DA rings. This relaxation was not affected by the NO synthase inhibitor L-NAME, the soluble guanylate cyclase (sGC) inhibitor ODQ, or the $\mathrm{K}^{+}$channel inhibitors TEA (non selective), 4-AP $\left(\mathrm{K}_{\mathrm{V}}\right)$, glibenclamide $\left(\mathrm{K}_{\mathrm{ATP}}\right)$, iberiotoxin $\left(\mathrm{BK}_{\mathrm{Ca}}\right)$, TRAM-34 $\left(\mathrm{IK}_{\mathrm{Ca}}\right)$, and apamin $\left(\mathrm{SK}_{\mathrm{Ca}}\right)$. $\mathrm{CO}$ also relaxed $\mathrm{O}_{2^{-}}$ contracted $(60.8 \%$ relaxation) and $\mathrm{KCl}$-contracted $(18.6 \%$ relaxation) DAs. This relaxation was impaired by ODQ, TEA, and 4-AP, suggesting the involvement of sGC and $\mathrm{K}_{\mathrm{V}}$ channel stimulation. The presence of inhibitors/precursors of $\mathrm{H}_{2} \mathrm{~S}$ or CO synthesis did not significantly affect the response of the DA to $\mathrm{O}_{2}$.

Conclusions: Our results indicate that the gasotransmitters $\mathrm{H}_{2} \mathrm{~S}$ and $\mathrm{CO}$ are vasoactive in the chicken DA but they do not suggest an important role for endogenous $\mathrm{H}_{2} \mathrm{~S}$ or $\mathrm{CO}$ in the control of chicken ductal reactivity. 